\title{
The influence of Carl Linnaeus on the Encyclopaedia Britannica of 1771
}

\author{
Rosemarie Gläser
}

\section{Introduction}

The distinguished Swedish biologist, physician and mineralogist, Carl von Linné (1707-1778), known to the Latin-speaking scientific community of his time as Carolus Linnaeus - later admirers even hailed him as "the Pliny of the North" and "a new Newton" - had a considerable influence on the development of the sciences in the British Isles throughout the eighteenth century. Besides his lively correspondence with English and Scottish scholars and his short visits to botanical gardens in Chelsea and Oxford in 1736, he was acknowledged as an authority in the first Encyclopaedia Britannica of 1771. The breakthrough of the Linnaean classification system for plants and animals and the nomenclature for their denomination came with the decision of the editors and authors of this nationwide reference work to prefer Linnaeus's system to similar attempts by competing contemporaries.

It is to be assumed that Linnaeus was unaware of the impact his work had on the Encyclopaedia Britannica. English reference books had a rather limited circulation in the Latin-speaking international community of experts. Moreover, their distribution over great distances across the continent took a long time. Linnaeus did not know English, and in the 1770s he was suffering from ill health (Broberg 2007).

But Linnaeus most likely received reports of the preparations for the voyage of James Cook (1728-1779), astronomer and captain of the exploration ship the Endeavour, bound for Tahiti to observe the transit of Venus in 1769 and continuing from there into the South Sea. On this expedition, which resulted in the discovery of the east coast of Australia (in April 1770), Cook was accompanied by the English botanist Joseph Banks (1743-1820) and the Swedish botanist Daniel Solander (1735-1782), a well-known disciple of Linnaeus. Banks paid for all the botanical research equipment out of his own resources. Later on, Banks and Solander became members of the Royal Society in London. 
On his second expedition to the southern hemisphere (1772-1775), James Cook as captain of His Majesty's (George III) sailing ship the Resolution was once again accompanied by the botanists Banks and Solander, as well as by two younger disciples. Of great benefit to the crew and to their research work was the participation of the two German scientists Johann Reinhold Forster (17291778) and his 18-year-old son Johann Georg Forster (1754-1794), who later published the travelogue Reise um die Welt in English and German (17781780). The second ship that accompanied the Resolution from the very start was the Adventure, commanded by Captain Tobias Furneaux. (Cf. Forster 2007.)

Joseph Banks, on his first expedition, discovered between 1,200 and 1,500 new species in Botany Bay and described them according to the Linnaean system. Johann Georg Forster's travel report was a further confirmation of this established practice of botanical denomination. It is worth mentioning that Forster's travel reports were the first publication in this genre to be based on strictly scientific observation and description. Moreover, they were enriched by realistic illustrations depicting ethnic groups, local scenery, and indigenous flora and fauna named according to the Linnaean system.

Against this background, the present article sets out to elaborate the repercussions of Linnaeus's work as a biologist and physician in the Encyclopaedia Britannica of 1771 . This will be exemplified by instructive passages drawn from articles and treatises included in that work of reference. After a brief comment on the Swede's connections with English and Scottish scholars, and a general presentation of the first Encyclopaedia Britannica, the discussion will focus on prominent articles in the fields of botany, zoology, and medicine which reveal the influence of Linnaeus's work.

\section{Linnaeus's connections with British scholars}

When Linnaeus left Sweden for the European continent ("Ad Exteros") in February 1735, in the company of his friend Clas Sohlberg, his main concern was to acquire the academic degree of a doctor of medicine at the University of Harderwijk in Holland. This accomplishment was achieved with a disputation on "cold fever" on June 12, 1735. (Cf. Schwede 1980.)

During the three years of his stay in Holland, Linnaeus expanded his contacts with leading botanists. He visited $\mathrm{H}$. Boerhaave in Leiden. Of great importance to Linnaeus was George Clifford in Hartekamp, a versatile personality who was not only a doctor of law, but also a successful banker and the director of the East India Company. He made Linnaeus the supervisor of his private zoological and botanical gardens. The outcome of this work was Linnaeus's 
survey entitled Musa Cliffortiana florens Hardecampi (published in Leiden in 1736).

In 1735 Linnaeus succeeded in getting his major work Systema naturae published in Holland, which enabled him to send copies to scholars abroad, including in England. In the same year Clifford commissioned Linnaeus to travel to England to acquire some rare plants for his own botanical collection and to extend his scholarly contacts. In great detail Linnaeus recorded his stay in England in his later Vita. In Chelsea (London) he met the well-known botanist Dr Hans Sloane (1660-1753), a scientist who had travelled widely and even regarded himself as one of Linnaeus's disciples, as he had applied observations from the Systema naturae in his own studies of plants. Moreover, he was president of the Royal Society in London between 1727 and 1740.

Linnaeus's contact with the distinguished botanist Johann Jakob Dillenius (1687-1747), whom he visited in Oxford, was very productive. The first meeting of the two scholars was to some extent overshadowed by misunderstandings, because Dillenius, who had only read part of the Systema naturae at that time, was of the opinion that Linnaeus had directed his book against him. After this initial disharmony was overcome, their cooperation became fruitful. Dillenius even invited Linnaeus to stay in Oxford and to become a university professor. The Swedish botanist was offered the demanding and meritorious project of revising and enlarging the Pinax theatri botanici, written by William Sherard in 1623. The Greek word Pinax in the title ('writing tablet', 'picture') was a metaphorical description for a scholarly work. The original botanical survey included 6,000 plants. Dillenius, however, intended a new edition that was to include systematic botanical knowledge of 16,000 plants. (Cf. comment of Sieglinde Mierau in Carl von Linné 1980: 352.) For a number of personal reasons, Linnaeus felt obliged to decline this generous offer and returned to Sweden via Holland, where Clifford had covered the expenses for his journey to England (cf. Goerke 1989).

Throughout his lifetime, Linnaeus sustained a lively correspondence in Latin with scholars in many countries; 5,500 of his letters have been preserved (cf. Jönsson, this volume). In his Vita, Linnaeus enumerated his correspondents according to their academic degree and their place of work. The column "Anglia" includes the following names: Petrus Collinsonus (Mercator curiosus, Londini); Joh. Mitchell (Medicus ex Virginia, Londini); Isacus Schotus Lawsonus (Med. exercitus); Johan Andrew (Medicinae doctor Oxoniis); Joh. Jacob Dillenius (Prof. botan. Oxonii); Humphredus Sipthorn (Prof. botan. Oxonii); and Jacobus Donell (Medicus Irlandiae Cashel). (Cf. Carl von Linné 1980: 230.)

Linnaeus was acknowledged in academic circles of England and Scotland and honoured in many ways. In 1762 he was appointed an honorary member of 
the Royal Society of London, and in 1773 of the Medical Society in Edinburgh (“Edinburgensis Coll. Med.”).

\section{The first Encyclopaedia Britannica of $\mathbf{1 7 7 1}$}

The British society in the second half of the eighteenth century witnessed the appearance of two most influential works of reference, intended for a broader readership beyond the limited circles of the educated middle classes and the aristocracy. These books were the Dictionary of the English Language, designed and compiled, as an individual achievement, by Dr Samuel Johnson and appearing in 1755, and the Encyclopaedia Britannica, elaborated by "a Society of Gentlemen in Scotland" and published in three volumes in 1771. While Dr Johnson's work A Dictionary of the English Language codified the contemporary literary and colloquial vocabulary as to its meaning, etymology, usage and regulated spelling, the Encyclopaedia Britannica, also called A Dictionary of Arts and Sciences [...], was a huge thesaurus of theoretical and practical knowledge, and a reflection of dominant paradigms in particular areas of research. The extended title on the frontispiece of the Encyclopaedia Britannica presents the editors' goal of achieving a compilation of knowledge upon a new plan, in which the different Sciences and Arts are digested into distinct Treatises or Systems; and the various Technical Terms, etc. are explained as they occur in the order of the Alphabet.

The idea of the wording of the title page - conveying both information and an implicit advertisement - is resumed in the preface. The authors have a definite pragmatic aim in mind which is put forward as quite a rigorous principle: "Utility ought to be the principal intention of every publication. Wherever this intention does not plainly appear, neither the books nor their authors have the smallest claim to the approbation of mankind. To diffuse knowledge on Science, is the professed design of the following work" (Vol. I, Preface, page V).

The procedure of the authors, in pursuing this aim, is exactly that of compiling knowledge drawn from distinguished publications of European authors past and present, many of them writing in Latin, and of presenting the most recent, innovative ideas by describing the state of the art in such fields as botany, zoology, and medicine, where Linnaeus was an undisputed authority.

In its essence, the Encyclopaedia Britannica mirrors the spirit of enlightenment and confidence in the progress of mankind. This conviction was also expressed in the famous contemporary French work of reference, the Encyclopédie française ou Dictionnaire raisonné des sciences, des arts et des métiers (1751-1777). The editors of the Encyclopaedia Britannica, in their preface, 
made a direct reference to this source. The French encyclopedia was composed of 28 volumes. It was designed, prepared and supervised by Denis Diderot (1713-1784) and Jean-Baptiste le Rond d'Alembert (1717-1783). In their depth of knowledge and presentation of the progress made in science and technology, both the French and the English encyclopedias demonstrate intellectual vigour, pride in the achievements of the unlimited human mind, and confidence in the advancement of the human race.

In the field of biology, the French encyclopedia propagated the ideas of Buffon (1707-1788) and disregarded those of Linnaeus altogether (cf. Sörman, this volume). On the other hand, its English counterpart mentioned Buffon's main work, Histoire naturelle, only briefly in the "List of Authors", whereas Linnaeus is represented by no less than six titles (Systema naturae; Amonitates academicae; Philosophia botanica; Genera plantarum; Species plantarum; and Fundamenta botanica). This bibliography is highly incomplete; there is no reference to time and place of publication. Moreover, the French botanist appears under the spelling Bouffon.

\section{Repercussions of Linnaeus's work in prominent articles of the Encyclopaedia Britannica}

In the eighteenth century, the specific fields of the modern natural sciences were not yet clearly defined. The three kingdoms of nature at that time were those of plants, animals, and minerals. Their corresponding scientific disciplines, botany, zoology and mineralogy, however, were still included in the all-embracing study of natural history - an umbrella term with far-reaching theoretical and practical implications. The spelling of the headwords in capital letters follows the original usage of the first Encyclopaedia Britannica.

\subsection{Botany}

The Encyclopaedia Britannica of 1771 contains a long, independent treatise of 24 double- column pages on BOTANY (Vol. I, 635 ff.), whereas the field of ZOOLOGY, "the science of animals", has only a short reference to the article on NATURAL HISTORY (Vol. III, 953), and the term MINERALOGY is not even referred to the entry on MINERAL, "in natural history [...] used, in general, for all fossil bodies [...] dug out of a subterraneous mine from which it takes its denomination" (Vol. III, 248). 
Strong evidence of the impact which Linnaeus had on the development of botany in the eighteenth century is the fact that the authors of the treatise on BOTANY in the first Encyclopaedia Britannica deliberately decided in favour of his system for the classification of plants and animals. This decision was an overt preference for Linnaeus over his predecessors and contemporaries, and further disseminated his work in western Europe. The writers of the article on BOTANY enter into an implicit dialogue with their readers:

We observed in the former section, that in the progress of this part of botany many different methods had been followed by different authors. Caesalpinus, Ray, Bauhinus, Van Royan, Ricinus, Tournefort, Linnaeus, Sauvages have each adopted a peculiar method of characterizing and classing plants. It would be foolish to distract the attention of the reader by an explanation of all these methods. We shall therefore proceed to explain that of Linnaeus, which is perhaps the only one now taught in Europe. (Vol. I, 635, my emphasis)

It is interesting to note that the name of the French natural scientist, Buffon, the great rival of Linnaeus, is not even mentioned in the list of classification systems quoted above.

The following passage of the text elaborates the survey of the sexual system presented by Linnaeus. It is illustrated by a plate of 24 types of plants. The authors of the article on BOTANY provide a condensed survey:

This method of reducing plants to classes, genera, and species, is founded upon the supposition that vegetables propagate their species in a manner similar to that of animals. Linnaeus endeavours to support this hypothesis by the many analogies that subsist between plants and animals. (...) It is from this circumstance that Linnaeus's system of botany got the name of the sexual system. The names of his classes, orders \& are all derived from this theory. He calls the stamina of flowers the males, or the male parts of generation; and the pistils females, or the female parts of generation. Plants whose flowers contain both male and female parts, are said to be hermaphrodites, etc. His classes, orders, and genera, are all derived from the number, situation, proportion, and the other circumstances attending these parts, as will appear from following scheme. (Vol. I, 635. Italics in the original)

Linnaeus's botanical system is elaborated in greater detail on 19 printed pages (in double columns) and in six plates containing drawings of the essential features of plants.

\subsection{Zoology}

As mentioned above, the subject of zoology is not treated in an independent article in the encyclopedia. It constitutes a separate part of the treatise on NAT- 
URAL HISTORY. In this context, the authors emphasize the analogy between the classifications of plants and animals in Linnaeus's system, with reference to their use of the same terminology and logical principles: "NATURAL HISTORY, is that science which not only gives compleat [sic] descriptions of natural productions in general, but also teaches the method of arranging them in Classes, Orders, Genera, and Species. This definition includes Zoology, Botany, Mineralogy, etc." (Vol. III, 362).

The headword for individual animals is "their proper name" (in English), with a reference to the Latin term for the genus or species.

In the following passage, the authors give an abridged survey of Linnaeus's system of animals:

Linnaeus divides the whole animal kingdom into 6 classes. The characters of these 6 classes are taken from the internal structure of animals, in the following manner.

Class I. MAMMALIA (mammals)

Class II. AVES, or Birds

Class III. AMPHIBIA, or Amphibious Animals

Class IV. PISCES, or Fishes

Class V. INSECTA, or Insects

Class VI. VERMES, or Worms

(Vol. III, 362)

The whole article on the subject of NATURAL HISTORY is limited to three and a half pages. The authors, however, present basic definitions of the key concepts which underlie the categories of Linnaeus's classification system and are derived from propositions of logic: "GENUS in natural history, a subdivision of any class or order of natural beings, whether of the animal, vegetable, or mineral kingdoms, all agreeing in certain common characters" (Vol. II, 673). SPECIES as defined in different entries (in Vol. III, 620) is an ambiguous term, as it is related to several fields of knowledge, ranging from logic to optics and commerce. In the system of biological entities, the concept SPECIES is understood in a logical sense: "a relative term, expressing an idea which is comprised under some general one called a genus" (Vol. III, 620). The concept of the next higher category, class, is clearly defined: "CLASS, an appellation given to the most general subdivisions of any thing; thus, animal is subdivided into the classes quadrupeds, birds, fishes, \& which are again subdivided into series or orders, and these last into genera. See NATURAL HISTORY, and BOTANY" (Vol. II, 207).

Throughout the Encyclopaedia Britannica, these defined categories are consistently applied by the authors of the entries on items of biology. 


\subsection{Medicine}

To his contemporaries Linnaeus was not only the famous botanist, zoologist and mineralogist, but also a knowledgeable doctor of medicine who had graduated in Holland. His reputation in this field was soon acknowledged in the British Isles. Consequently, the authors of the Encyclopaedia Britannica paid particular attention to Linnaeus in the comprehensive treatise on MEDICINE (in Vol. III, $58 \mathrm{ff}$.). The pertinent passage reads:

Of late several attempts have been made to reduce medicine into the form of a regular science, by distributing diseases into classes, orders, genera, and species. Sauvage was the first, and indeed the only person who ever attempted to complete this great work. Others, as Linnaeus, Vogel, Dr Cullen, etc., have since endeavoured to improve Sauvage's method of classing; but they have contented themselves with an enumeration of the characters and arrangement of the different genera, without entering into their history or cure. Sauvage enumerates 315 genera, Linnaeus 325, Vogel 560, and Dr Cullen has reduced them to 132. The bare inspection of these numbers shews [sic], that physicians are far from being agreed with regard to what constitutes the generic or specific characters of a disease. (Vol. III, 58)

This passage gives evidence of the state of the art in applying a biological nomenclature of genera to diseases. It is noteworthy that Linnaeus had made a significant contribution to this debate.

\section{Articles on agricultural animals and domestic pets}

The subject areas AGRICULTURE and HUSBANDRY in the Encyclopaedia Britannica of 1771 include a number of most informative articles on farm animals used for tillage, and of others raised for meat, milk, wool or leather production. All these animals are described with regard to their utility to the farmer. This idea is also evident in the articles on domestic animals kept for man's company, and naturally in the description of detrimental rodents and other vermin occurring in the farmyard.

The headword of each article consists of the Latin genus name of the particular animal according to the Linnaean system. As a rule, the English common (trivial) name is mentioned in the following explanatory text. Additional articles relating to the male, female and young animal are included under the English animal name as the headword. This procedure may be illustrated by the following examples: EQUUS (horse, mare, stallion, foal, colt); BOS (ox, cow, calf); OVIS (sheep, ram, ewe, lamb); CAPRA (goat); SUS (pig, sow, swine); 
PHASIANUS (poultry, cock, hen); ANAS (an umbrella term for both goose and $d u c k$ ). The domestic animals with a more social function are CANIS (dog, bitch) and FELIS (cat). However, the designations puppy and kitten for the young of these animals are missing.

In general, the articles are introduced by a description of the anatomical and physiological features of the animal. This text segment offers essential zoological facts in an unemotional, neutral style and is strikingly different from the character images that follow. In the latter, the author usually describes the properties and behaviour of the particular animal in relation to human attitudes and moral standards, using emotive means of expression. This overt style shift suggests the conclusion that another person was in charge of these character sketches. From an anthropomorphic viewpoint, the author expresses his personal value judgement of a farm animal by a wide variety of figurative stylistic means. (Cf. Gläser 2006.)

It goes without saying that animal character images like these are not the result of theoretical principles or psychological case studies (not yet applied in the eighteenth century), but rather reiterate popular clichés and stereotypes about domestic animals. Moreover, the authors of the articles suggest a certain hierarchy of character images. The highest position of appreciation is occupied by the horse, the lowest by the pig. In these descriptions, the animal is often personified, and grammatically the male gender (he, his) prevails.

The horse, EQUUS (genus name), belongs to the order of BELLUAE and shares genetic properties with the ass (genus ASINUS) and the zebra. The domesticated horse receives an excellent character image in the following description:

The horse, in a domestic state, is a bold and fiery animal; equally intrepid as his master, he faces danger and death with ardour and magnanimity. He delights in the noise and tumult of arms, and seems to feel the glory of victory; he exults in the chase; his eyes sparkle with emulation in the course. But though bold and intrepid, he is docile and tractable; he knows how to govern and check his natural vivacity and fire of his temper. (Vol. II, 506)

This heroic type of horse, reminding the reader of a charger, differs greatly from the horse as a pack, riding or draught animal:

He not only yields to the hand, but seems to consult the inclination of his rider. Constantly obedient to the impressions he receives, his motions are entirely regulated by the will of his master. He in some measure resigns his very existence to the pleasure of man. He delivers up his whole powers; he reserves nothing; he will rather die than disobey. Who could endure to see a character so noble abused! Who could be guilty of such gross barbarity! (Vol. III, 506, my emphasis) 
By the standards of a modern encyclopedic reference book, this exalted and pathetic presentation of a working horse and the anthropomorphic interpretation of its behaviour would be totally inappropriate. But animal protection campaigners might draw supporting arguments from the author's defence of the horse.

A much less favourable character is attributed to the ass (genus ASINUS):

The ass is as humble, patient, and tranquil, as the horse is bold, ardent and impetuous. He submits with firmness, perhaps with magnanimity, to strokes and chastisement; he is temperate both as to the quantity as to the quality of his food; he contents himself with the rigid and disagreeable herbage which the horse and other animals leave to him, and disdain to eat; he is more delicate with regard to his drink, never using water, unless it be perfectly pure. (Vol. II, 510)

The ox (genus BOS), too, is measured against the quality scale of the male horse. However, the bull fighting in the arena differs greatly in appearance and performance from the ox drawing the plough. The author of the article presents an ideal picture of this farm animal:

A bull, like a stallion, should be the most handsome of his species. He should be large, well made, and in good heart; he should have a black eye, a fierce aspect, but an open front; a short head; thick, short and blackish horns, and long shaggy ears; a short straight nose, large and full breast and shoulders; thick and fleshy neck, firm reins; a straight back; thick, fleshy legs, and a long tail well covered with hair. (Vol. I, 624)

This description of a desirable type (or specimen) of an ox could be understood as a practical guide for a farmer intending to purchase oxen at a cattle market or auction. The main purpose of the ox in the British Isles in the author's opinion is "to propagate the species; although he might be trained to labour, his obedience cannot be depended on".

The goat (genus CAPRA) seems to be held in higher esteem by the article writer than the sheep, being regarded as more intelligent, more independent, less timid, more sociable and more tameable. Moreover, the goat seems to like being petted (like indoor cats). The author presents the following character image:

The goat is an animal of more sagacity than the sheep. Instead of having an antipathy at mankind, they voluntarily mingle with them, and are easily tamed. Even in uninhabited countries, they betray no savage dispositions (...) Goats are sensible of caresses, and capable of a considerable degree of friendship. They are stronger, more agile, and less timid than sheep. They have a lively, capricious, and wandering disposition; are fond of high and solitary places, and frequently sleep upon the very points of rocks... (Vol. II, 30) 
The author's description of the sheep follows the utility principle entirely. This farm animal is a provider of milk, meat, wool, leather and tallow. It is susceptible to heat and cold. Its blind herd instinct may expose it to danger in mountainous areas. The author introduces his observations on the ram (or ARIES) as follows: "This animal is perhaps the most gentle and inoffensive, and at the same time the most timid and stupid of all quadrupeds" (Vol. III, 447).

Placed at the bottom end of the likeability scale of farm animals, the pig (genus SUS) is given a very unfavourable character image. Its ugly appearance, dirty way of feeding and unsavoury housing conditions are disgusting to the writer of the article, and the quality of pork is not recommended:

The sus scrosa, or common sow, is a native of the southern parts of Europe. It feeds coarsely, digs up roots, etc., from the ground with its snout. It is a fat, sleepy, stupid, dirty animal, wallowing constantly in the mire. The sow brings forth a great number of young at a litter, and is therefore considered as a profitable animal. The flesh, however, is not reckoned to be of the most wholesome kind. (Vol. III, 879)

From a quite different perspective, the dog and the cat as familiar housemates of man do not enjoy equal recognition by the authors of the respective encyclopedia articles. The dog (genus CANIS, order FERAE), originally stemming from the domesticated wolf, is characterized by his fidelity and reliability to his master:

In a savage state, he is fierce, cruel, and voracious, but, when civilized and accustomed to live with men, he is possessed of every amiable quality. He seems to have no other desire than to please and protect his master. He is gentle, obedient, submissive, and faithful. Those dispositions, joined to his almost unbounded sagacity, justly claim the esteem of mankind. Accordingly no animal is so much caressed or respected: He is so ductile, and so much formed to please, that he assumes the very air and temper of the family in which he resides. (Vol. II, 23)

In this respect, the dog and the horse may be regarded as man's most reliable friends. On the other hand, the author's value judgement of the domestic cat (genus FELIS) is far from favourable. The author concedes that the cat is useful for catching mice and rats in the house, garden, barn and storehouses. But it is ascribed human properties such as unreliability, unpredictability and cunning:

Of all domestic animals, the character of the cat is the most equivocal and suspicious. He is kept, not for any amiable qualities, but purely with a view to banish rats, mice, etc., and other noxious animals from our houses, granaries, etc. Although cats, when young, are playful and gay, they possess at the same time an innate malice and perverse disposition, which increases as they grow up, and 
which education learns them to conceal, but never subdue. Constantly bent upon theft and rapine, though in a domestic state, they are full of cunning and dissimulation; they conceal all their designs, they seize every opportunity of doing mischief, and then fly from punishment. They easily take on the habit of society, but never its manners, for they have only the appearance of friendship and attachment (...) In a word, the cat is totally destitute of friendship; he thinks and acts for himself alone. (Vol. II, 586)

In a different frame of reference, parts of this extremely anthropomorphized description of an animal's character could evoke associations with a human criminal who constantly varies his tactic and strategy to do harm to society. This one-sided and biased description of the "prototypical" domestic cat is an exception in eighteenth-century English literature. There are numerous opposite examples of a happy community of single persons or families and cats, and Samuel Johnson was known as a great cat-lover.

On the whole, from a scientific perspective, the passages on the character of domestic animals are untenable and incompatible with the anatomical descriptions provided by Linnaeus and his contemporaries. Most likely, they result from the author's intention to include popular rural knowledge for the reader's entertainment.

\section{Summary}

After the appearance of the first Encyclopaedia Britannica in 1771, profound changes occurred in the political, economic and cultural life of British society, giving rise to diversified demand on the book market and eventually preparing the ground for a second, considerably enlarged edition of this comprehensive work of reference. Its editors thought it essential that the articles and larger treatises kept pace with current improvements in British husbandry, with technological progress in industrial production, and with the advancement of the sciences, arts, and trades promoted by the Royal Society in London, whose president was Joseph Banks, an ardent adherent of Linnaeus.

Another strong impetus came from the records of the voyages (in 17691770 and 1772-1775) of Captain James Cook and the scientists and naval officers accompanying him, reporting on the discovery of Australia and describing its remote flora and fauna according to the Linnaean system. A wealth of topical information was thus available to the authors and editors, lending further confirmation to the utility principle, the pragmatic guideline of their procedure.

The second Encyclopaedia Britannica appeared between 1777 and 1784, a huge reference work in 10 volumes, covering 8,595 printed pages and includ- 
ing many illustrations. The editor was James Tytler (1747-1804). Among its considerable improvements were the biographical and geographical articles reporting on the latest transatlantic and trans-Pacific voyages of explorers and scientists.

The third Encyclopaedia Britannica followed as early as 1788, comprising 18 volumes and 14,573 pages. The editor was Colin Macfarqhar, who remained in charge of this project until his death in 1793. It was completed by the Scottish clergyman George Gleig (1753-1840) in 1797. With these three editions, the tradition of the Encyclopaedia Britannica lasting to the present day was inaugurated. To the English-speaking readership of the eighteenth century, it became a universal thesaurus of knowledge, and one in which Carl Linnaeus, too, has sunk deep roots.

\section{References}

Broberg, Gunnar

2006 Carl von Linné. Übersetzung: Margaretha Tidén. Stockholm: Schwedisches Institut.

Broberg, Gunnar

2007 Linnaeus, Scientist or Man of Letters? Plenary Paper at the International Symposium on the Languages of Science in the Time of Linnaeus, June 7-9, 2007, Uppsala, Sweden. Collected Abstracts, pp. $14 / 15$ and oral discussion contribution.

Emersleben, Otto

1998 James Cook. Reinbek bei Hamburg: Rowohlt.

Encyclopaedia Britannica; or, A Dictionary of Arts and Sciences, Compiled upon a new plan, in which the different Sciences and Arts are digested into distinct Treatises or Systems, and the various Technical Terms are explained as they occur in the order of the Alphabet. By a Society of Gentlemen of Scotland. In Three Volumes, Edinburgh MDCCLXXI. Reprint 1989. (Original title.)

Encyclopaedia Britannica

2003 Macropedia. Ready Reference. Fifteenth edition. Article "Encyclopædia Britannica", p. 487. Chicago etc.

Forster, Georg and Georg Christoph Lichtenberg

1976 Cook der Entdecker. Schriften über James Cook. Leipzig: Verlag Philipp Reclam jun. 
Forster, Georg

2007

Reise um die Welt. Audiobook, read by Frank Arnold. Eichborn Lido.

Gläser, Rosemarie

2006

Die Themenkomplexe Gartenbau und Landwirtschaft in der Encyclopaedia Britannica von 1771 - eine fachsprachengeschichtliche Untersuchung. In: Petr Rösel (ed.), English in Space and Time. Englisch in Raum und Zeit. Forschungsbericht zu Ehren von Klaus Faiß. Fokus. Linguistisch-philosophische Studien, 31, Trier: WissenschaftGoerke, Heinz 1989

Carl von Linné. Arzt, Naturforscher, Systematiker. 2. Auflage. Stuttgart: Wissenschaftliche Verlagsgesellschaft.

Linné, Carl von 1980

Lappländische Reise und andere Schriften. Leipzig: Verlag Philipp Reclam jun.

Schwede, Alfred Otto

Carl von Linné. Der Blumenkönig des Nordens. Berlin: Union Verlag. 